\title{
Experimental Investigation on Concrete with Replacement of Fine Aggregate by Lathe Waste
}

\author{
Hemanth Tunga G N ${ }^{\# 1}$, Rasina $\mathrm{K} \mathrm{V}^{* 2}$, Akshatha $\mathrm{S} \mathrm{P}^{\# 3}$ \\ ${ }^{\#}$ Assistant Professor, Department of Civil Engineering, \\ Alva's Institute of Engineering and Technology, Moodbidri. \\ hemanthtunga@aiet.org.in \\ *UG Scholar, Department of Civil Engineering, \\ Alva's Institute of Engineering and Technology, Moodbidri. \\ rasnakv2489@gmail.com³aksp880@gmail.com
}

\begin{abstract}
Concrete being the most important and widely used material is called upon to possess very high strength and sufficient workability properties. Today the construction industry is in need of finding cost effective materials for increasing the strength of concrete structures. Hence, there is a need to identify and use of materials that reduce use of natural resources and increase use of waste products. Great quantities of steel waste fibers are generated from industries related to lathe. Therefore, an attempt has been made in the present investigation to study the influence of addition of waste material like lathe waste as a replacement to fine aggregate. In the present experimental investigation, an attempt will be made to analyze the mechanical characteristics of the waste Steel Scrap material which is available from the lathe machine is used as a Lathe waste in cement concrete for various construction works and to optimize fibre content. The outcome of this project shall be useful for various industries and workshop generating steel scrap from lathe machine.
\end{abstract}

Keywords - Lathe waste, Steel fiber, Compressive strength, Split-tensile strength.

\section{INTRODUCTION}

Generally, concrete consists of cement, fine aggregate, coarse aggregate. Their proportion in the concrete is based on grade of concrete and it determines the strength also. Nowadays use of resources in the construction industry is high. This project is to replace the material in concrete for better improvement of concrete properties .the main aim of for this project is to avoid soil infertility, land filling, and environmental hazards creates by industrial waste. The characteristics of concrete with partial replacement of sand by steel lathe waste to standard M25 grade concrete are investigated in this study. Various other experimental studies conducted on lathe scrap reinforced concrete showed that there is considerable increase in the compressive strength when compared to plain cement concrete and also when tested for flexural strength, the lathe scrap reinforced concrete shows an increase in flexural strength to great extent. In this study, fine aggregate is being replaced with lathe waste at various percentages like $2 \%, 4 \%, 6 \%$ and $8 \%$ and characteristics of concrete like compressive strength, split-tensile strength are to be studied.

\section{MATERIALS}

\section{A. Cement}

Literally, cement means a binding material. It has the property of setting and hardening when mixed with water to attain strength. The cement may be natural or artificial. Natural cement is manufactured by burning and then crushing natural cement stones, which contain argillaceous and calcareous matter. Artificial cement is manufactured by burning appropriately proper proportioned mixture of argillaceous and calcareous materials at a very high temperature and then grinding the resulting burnt mixture to a fine powder. Ordinary Portland cement of good consistency and grade 43 is used in this project.

TABLE I. Cement Test Results

\begin{tabular}{|c|c|c|}
\hline Particulars & Cement & Limits as per IS 8112(1989) \\
\hline Specific gravity & 3.13 & Not more than 3.15 \\
\hline Initial setting time & $45 \mathrm{~min}$ & Not less than $30 \mathrm{~min}$ \\
\hline Final setting time & $472 \mathrm{~min}$ & Not more than $600 \mathrm{~min}$ \\
\hline
\end{tabular}




\section{B. Fine Aggregate}

The material which is passed through $4.75 \mathrm{~mm}$ IS sieve is termed as Fine Aggregate. Usually natural river sand conforming zone II was used as fine aggregate. The specific gravity of fine aggregate is 2.63.

TABLE III. Fine Aggregate Tests Results

\begin{tabular}{|c|c|c|}
\hline Particulars & Fine Aggregate & Limits as per IS 383(1970) \\
\hline Specific gravity & 2.63 & Not more than 3.15 \\
\hline Water absorption & $1.69 \%$ & Not less than 30 min \\
\hline
\end{tabular}

\section{Coarse Aggregate}

The material which is retained on $4.75 \mathrm{~mm}$ size IS sieve is termed as a coarse aggregate. Broken stone is generally used as an aggregate. Natural crushed aggregate with maximum size of $20 \mathrm{~mm}$ is used. The specific gravity of coarse aggregate is 2.67 .

TABLE III. Coarse Aggregate Test Results

\begin{tabular}{|c|c|c|}
\hline Particulars & Coarse Aggregate & Limits as per IS 383(1970) \\
\hline Specific gravity & 2.67 & 2.75 \\
\hline Impact value & $28.2 \%$ & $35 \%$ \\
\hline Crushing value & $27.4 \%$ & $35 \%$ \\
\hline Elongation index & $33.22 \%$ & $45 \%$ \\
\hline Flakiness index & $27.22 \%$ & $45 \%$ \\
\hline
\end{tabular}

\section{Lathe Waste}

Lathe scarps are the waste materials which are collected from workshops and other steel industries. They are similar to the steel fiber but they don't have any regular shape and size. These scraps in the powder form which is used as a reinforcing material in concrete to enhance the various properties of concrete.

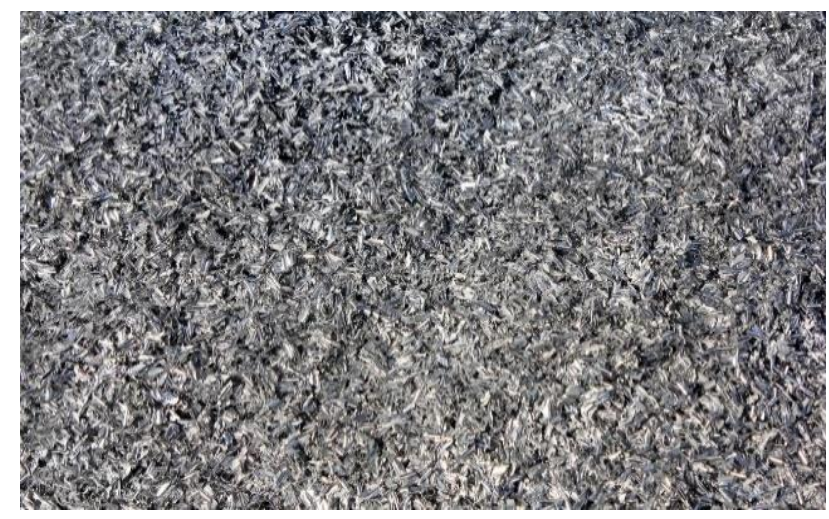

Figure 1: Lathe Waste

\section{MIX PROPORTIONS FOR CONCRETE}

The concrete used for the study is of M25 grade. The mix design is carried out as per the guidelines of IS 10262 (2009). The mix proportions of the concrete were 1:1.4:2.8:0.5 (Cement:Fine Aggregate:Coarse Aggregate:Water-Cement ratio). Lathe waste in the order of $2 \%, 4 \%, 6 \%$ and $8 \%$ is used in concrete as a replacement of fine aggregate. The mixing can be done manually.

\section{RESULTS AND DISCUSSIONS}

The compressive strength test and split-tensile strength tests were conducted on prepared concrete specimens. The specimens were cured for 7 days and 28 days before testing. The results have been tabulated in the tables below.

\section{A. Compressive Strength Test:}

The compressive strength test has been conducted for conventional concrete (i.e., $0 \%$ replacement) and fine aggregate replaced by lathe waste. The fine aggregate is replaced by $2 \%, 4 \%, 6 \%$ and $8 \%$. The test results of 7 days and 28 days are shown in table IV and figure 2. 
TABLE IV. Compressive Strength Test Results

\begin{tabular}{|c|c|c|}
\hline $\begin{array}{c}\text { Percentage of Lathe } \\
\text { Waste }\end{array}$ & $\begin{array}{c}\text { 7-days Compressive } \\
\text { Strength (MPa) }\end{array}$ & $\begin{array}{c}\text { 28-days Compressive } \\
\text { Strength (MPa) }\end{array}$ \\
\hline $0 \%$ & 21.50 & 26.55 \\
\hline $2 \%$ & 23.60 & 32.70 \\
\hline $4 \%$ & 22.40 & 29.49 \\
\hline $6 \%$ & 19.50 & 25.11 \\
\hline $8 \%$ & 18.45 & 23.50 \\
\hline \multicolumn{2}{|r}{} \\
\hline
\end{tabular}

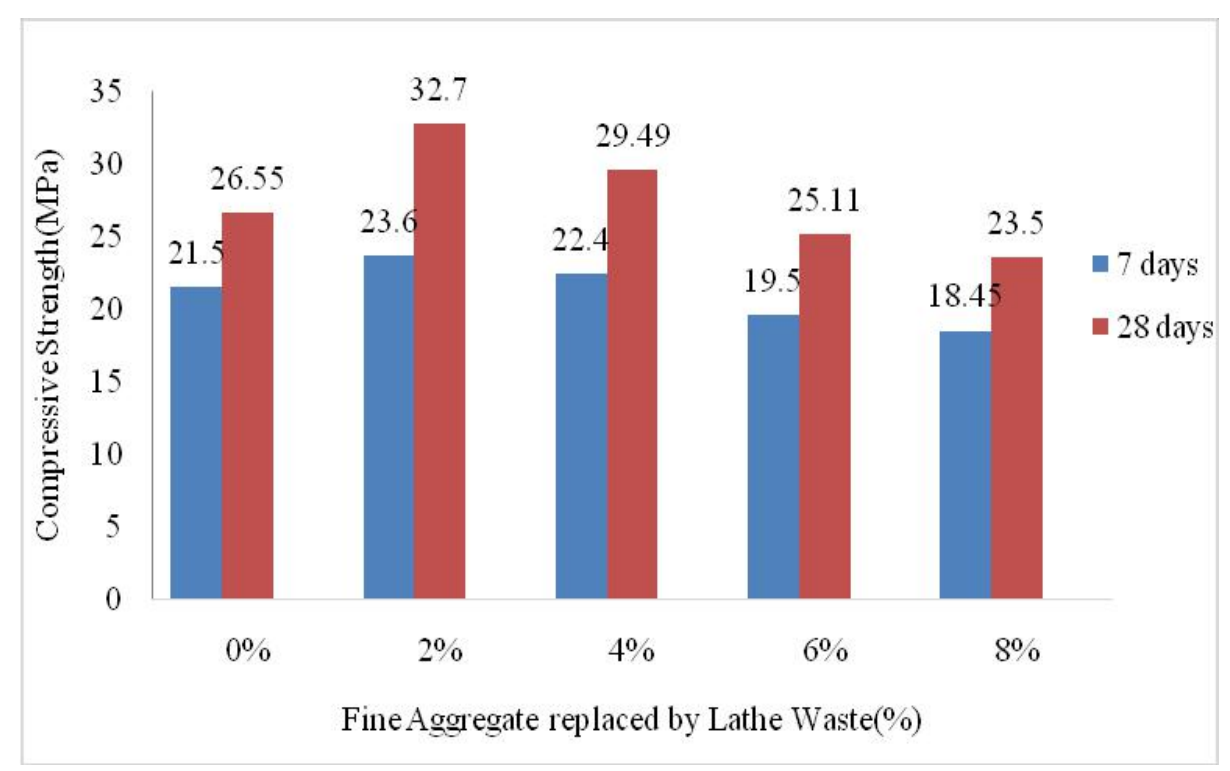

Figure 2: Graph Showing the Results of Compressive Strength Test

The above graph indicates that the compressive strength of 28 days with various percent of lathe waste added to concrete in replacement to fine aggregate (sand). The optimum strength gained after 28 days curing period is at $2 \%$ addition and lowest at $8 \%$ addition of lathe waste in replacement to fine aggregate. It is found that in replacement of $2 \%$ of lathe waste at 7 days, there was $9 \%$ increment in compressive strength when compared to conventional concrete. Whereas in the replacement of $2 \%$ at 28 days, there was an increment of $18.80 \%$ in compressive strength as compared to conventional concrete. When we observe the results of $4 \%$ replacement is higher than that of the conventional concrete. So, in order to minimise the waste generated, we can use replacements up to $4 \% \mathrm{n}$ the execution.

\section{B. Split-Tensile Strength Test:}

The split-tensile strength test has been conducted for conventional concrete (i.e., $0 \%$ replacement) and fine aggregate replaced by lathe waste. The fine aggregate is replaced by $2 \%, 4 \%, 6 \%$ and $8 \%$. The test results of 7 days and 28 days are shown in table $\mathrm{V}$ and figure 3.

TABLE V. Split-Tensile Strength Test Results

\begin{tabular}{|c|c|c|}
\hline $\begin{array}{c}\text { Percentage of Lathe } \\
\text { Waste }\end{array}$ & $\begin{array}{c}\text { 7-days Split Tensile } \\
\text { Strength (MPa) }\end{array}$ & $\begin{array}{c}\text { 28-days Split Tensile } \\
\text { Strength (MPa) }\end{array}$ \\
\hline $0 \%$ & 2.48 & 2.86 \\
\hline $2 \%$ & 2.85 & 3.25 \\
\hline $4 \%$ & 2.34 & 2.96 \\
\hline $6 \%$ & 2.22 & 2.57 \\
\hline $8 \%$ & 2.01 & 2.35 \\
\hline
\end{tabular}




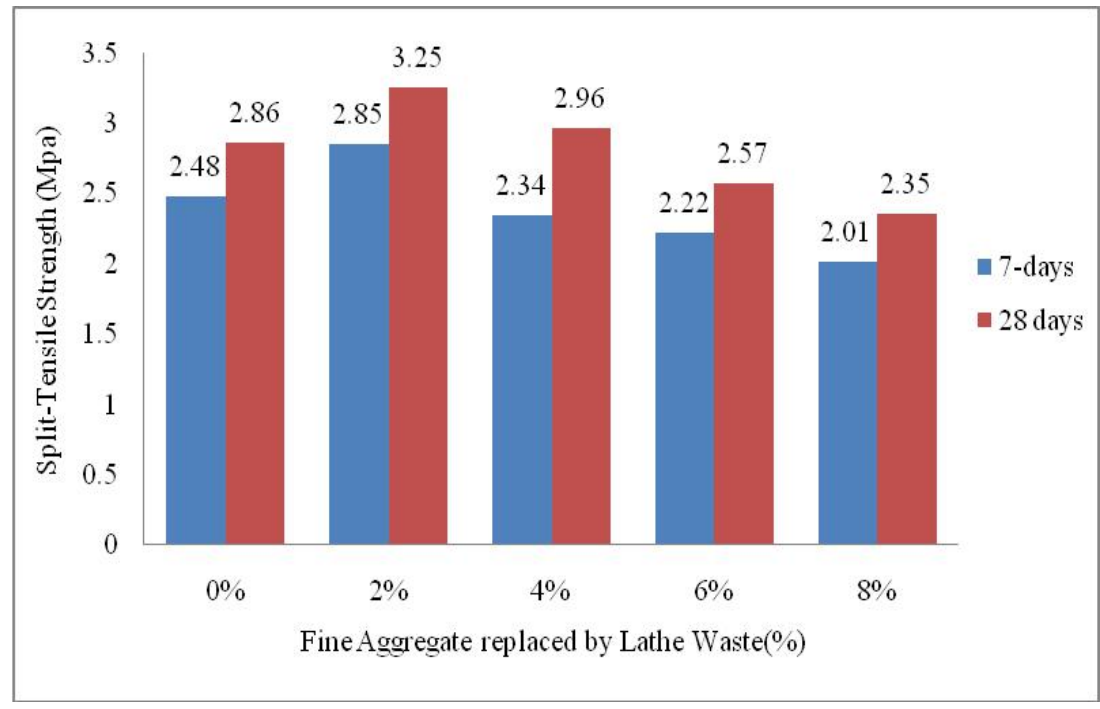

Figure 3: Graph Showing the Results of Split-Tensile Strength Test

It was found that the replacement of lathe waste in concrete increases the split tensile strength of concrete cylinder. For $0 \%, 2 \%$ and $4 \%$ of lathe waste content by weight of fine aggregate in concrete, the tensile strength obtained was $2.48,2.85$, and $2.34 \mathrm{MPa}$ respectively for 7 days. This indicates there is $13 \%$ of increment in splittensile strength when compared to conventional concrete. Whereas in the case of 28 days, for the replacement of $0 \%, 2 \%$ \& $4 \%$ obtained was $2.86,3.25$ and $2.96 \mathrm{MPa}$ respectively. There is $12 \%$ increment for $2 \%$ when compared to conventional concrete. We can see that $4 \%$ replacement of fine aggregate is also giving better result when compared to conventional concrete. So, we can use replacements up to $4 \%$ so that the utilisation of waste material can be increased.

\section{CONCLUSION}

This investigation shows that replacement of lathe waste improves mechanical properties of concrete. Various tests were done at 7 and 28 days after casting the specimens. The following conclusions were made from the test results and discussions of this investigation:

- When the fine aggregate was replaced with $2 \%$ of lathe waste, there was an increase of $18.8 \%$ in compressive strength test result. When fine aggregate is replaced with $4 \%$ of lathe waste, the increment in compressive strength test was $11 \%$ compared to conventional concrete, which indicated that the use of $4 \%$ replacement is also possible in order to maximise the waste utilisation.

- It was found that for $2 \%$ replacement, there will be $13 \%$ of increment in split tensile strength after 7 days and $12 \%$ after 28days. For $4 \%$ replacement, better result is obtained compared to conventional concrete.

- $\quad$ Natural resources are not unlimited and also, there is a global need to protect to our environment and preserve our scarce natural resources for next generation.

- $\quad$ Use of lathe waste in concrete is beneficial as compared to conventional concrete reduces the environmental pollution as well as providing economical value for the waste material.

\section{REFERENCES}

[1] Ashish Kumar Parashar and Rinku Parashar, "The effect of size of fibres on compressive strength of M-20 Concrete mixes". International Journal of Latest Research in Engineering and Computing (IJLREC) Volume 5, Issue 3, (61-66) May-June 2012.

[2] Hsiea,Chijen Tua,P.S.Song, "Mechanical Properties of Polypropylene Hybrid Reinforced Fibre Concrete”. International Journal of Engineering Research and General Science Volume 4 (ISSN 2091-2730), July-August 2008.

[3] G Vijayakumar, P Senthilnathan K Pandurangan and G Ramakrishna, "Impact and Energy Absorption characteristics of Lathe Scrap Reinforced Concrete”. International Journal of Structural \& Civil Engineering Research, Vol. 1, No. 1, (ISSN 2319-6009), November 2012.

[4] Job Thomas and Ananth Ramaswamy, "Mechanical Properties of Steel Fibre Reinforced Concrete”. International Journal of Structural \& Civil Engineering Research, Vol. 2, No. 1 (ISSN 2319-6009), 2012.

[5] Shirule Pravin Ashok., Swami Sunman and Nilesh Chincholka, "Reuse of Steel Scrap from Lathe Machine as Reinforced Material to Enhance Properties of Concrete”. Concrete International Journal, Vol. 7, No. 3, (21-25), 2012.

[6] Amrutha K, Ashirwad K, Freen K, Najila M, Praseedha R, "Partial replacement of fine aggregate by using lathe waste in concrete". International Research Journal of Engineering and Technology (IRJET), Vol. 4, (34-42), 2017.

[7] Vikrant S Vairagade, Kavita S. Kene, Tejas R Patil, "Comparative Study of Steel Fiber Reinforced Over Control Concrete”, International Journal for Scientific Research \& Development (IJSRD), Vol. 2, Issue 12, (253-298), 2012.

[8] Thirumurugan and M. Sivaraja Asian, "Workability and Strength Properties of Hybrid Fibre Reinforced Concrete from Industrial Waste”, Journal of Civil Engineering (BHRC) Vol. 14, No. 3, 2013. 